\title{
Effects of Knowledge Management Capabilities on Organizational Performance in Iranian Export Companies
}

\author{
Esmail Khodai Matin \\ Young Researchers Club, Islamic Azad University, Neyshabur Branch, Neyshabur, Iran \\ Email: matin.esmail@gmail.com
}

\author{
Parisa Sabagh \\ Department of Public Administration, Mashhad Branch, Islamic Azad University, Mashhad, Iran \\ Email: pari.sabbagh@gmail.com
}

\section{Doi:10.5901/mjss.2015.v6n2p240}

\section{Abstract}

The purpose of this study is to investigate the relationship between knowledge management capabilities and organizational performance. The knowledge management indices include knowledge process capabilities (knowledge acquisition, knowledge transfer, and knowledge protection and knowledge application) and knowledge infrastructure capabilities (organizational culture, organizational structure and technology),also organizational performance indices are organizational innovation and competiveness and financial/economical outcomes. The method of the study is structural equation modeling. Statistical population includes the entire senior managers of companies that are member of Khorasan Razavi Exporters Union. The sample size equals 148. Data collection tool is a standard questionnaire. SPSS and Lisrel software packages was used for analyzing research hypotheses. The result of confirmatory factor analysis determined that both research models are estimated significantly; also the result of path analysis determined that there is a direct and significant relationship between organizational culture, organizational structure, knowledge acquisition, knowledge application, knowledge protection and organizational performance. This study is the first study to this day to investigate the relationship between knowledge management and performance in Iran. So it is valuable for Iranian export companies to apply the results in terms of knowledge management and its effects on organizational performance.

Keywords: Knowledge management; Knowledge infrastructure capability; Knowledge process capability; Organizational performance; Structural equation

\section{Introduction}

There were many disputes about the significance of knowledge management in business world during the recent years (Metaxiotis and Ergazakis, 2008) such that leading the economy today to a knowledge-based one and the knowledge is considered as the most valuable asset and an important competitive factor in organizations (Rivera-Vazquez et al, 2009). Nowadays, many organizations are dependent on applying knowledge management in addition to successful application of tangible assets and natural resources to achieve high performance (Lee and Sukoco, 2007). For this reason, investment in knowledge management is increasing annually. According to the findings of AMR Research Inc., American organizations have invested 37 million dollars in knowledge management soft wares during 2007. This figure has grown 16 percent in 2008. Forrester Research Inc. also reported that 20 percent of North-American and European SMEs have planned to implement Customer Relationship Management (CRM) in 2010 (Mills and Smith, 2010). This statistics indicates the fastest growth in SMEs' software and shows that today, knowledge management is known as the main source of creating competitive advantage and business success.

Nowadays, application of knowledge for development is one of the challenges in developing countries. For this reason, knowledge based economy has been emphasized as a principal pillar in forth development plan. There is a scientific gap in this field in Iran and few studies has been done. So, the purpose of the current research is the knowledge of higher managers in the studied organizations about the organizational performance status and its interaction with knowledge management capabilities. Also, it can be possible to find the pros and cons of Iranian exporting organizations in the field of knowledge management and organizational performance, by comparing the results of the current research and other ones outside the country, and recommend proper solutions for more promotion. 


\section{Literature Review}

\subsection{Knowledge Management}

As Stonier stated, data is a series of realities and irrelevant observations which can turn to information by analysis, cross reference, selection, sorting, abstraction or organizing. Information models can be also converted to an integrated body of knowledge. Knowledge is composed of an organized body of information. These information models are the bases of insight and intelligence which is called wisdom (Zins, 2007).

As Tuomi (1999) stated it is accepted that data as raw material converts to information when they are in background and combine in a meaningful structure and subsequently information converts to knowledge when it is accompanied with experience and judgment. This view shows that data is the background of information and information is the background of knowledge (Tian et al, 2009).

Knowledge divide into implicit and explicit knowledge in managerial texts. According to Nonaka and Kano (1998) implicit knowledge exists in the individual's mind and its effects reveal in the individual's views, actions and habits which itself includes two types of knowledge: one forming cognitive knowledge (Perspectives and mental models), and the other individual's skills and technical knowledge. But there is another type of knowledge in an organization which can be easily computer processable, electronically transferred and stored in databases. Explicit knowledge can be expressed in words and numbers and shared in the form of data, formula, specifications, guidelines etc. This type of knowledge can be easily encoded and transferred formally and systematically between individuals (Matin and Kashani, 2012).

One of the main steps of organizational knowledge process is the conversion of explicit knowledge into implicit one (Lindner and Wald, 2010). Knowledge management occurs in an organization when these two types of knowledge can be converted to another which can create competitive advantage for organizations since explicit knowledge is common in nature. Implicit knowledge is the main challenge of knowledge management which its management can set the ground for individual and group learning, innovations and achievement of competitive advantage in organizations.

Due to the challenges in the definition of knowledge there is no common census on knowledge management term (Metaxiotis et al, 2005). Alavi and Lidner (2001) suggest that different perspectives on knowledge contribute to different inferences from knowledge management. If the knowledge is considered as a goal or equal to access to information, the knowledge management should be focused on the framework and the management should concentrate on knowledge storage.

But, if knowledge is seen as a superiority, knowledge management would concentrate on creating capabilities, understanding strategic advantages and producing intellectual capital.

Knowledge management framework involves activities such as knowledge recognition, acquiring, creation, storage, sharing and application by individuals and groups in the organization (Sun, 2010). In this regard, Van (2009) defines knowledge management as a set of procedures for creating, acquiring, sharing, and applying knowledge to excel the organizational performance.

It seems that the definition presented by Davenport and Prasak (1998) about knowledge management has been accepted by many researchers; knowledge management is employment and development of knowledge assets of an organization to achieve the organizational goals. This knowledge consists of both explicit and implicit knowledge (Theriou and Chatzoglou, 2007). The management of this knowledge involves all processes relevant to knowledge recognition, sharing and creation. This requires a system to produce and maintain knowledge repositories and promote and facilitate the knowledge sharing and organizational learning. Successful organizations in knowledge management consider the knowledge as a human capital and develop the organizational rules and values to support the knowledge production and sharing (Metaxiotis et al, 2005).

\subsection{Knowledge management capabilities}

With regard to the previous researches, the knowledge management capabilities divide into two categories of infrastructure capabilities and knowledge process capabilities (Gold et al, 2001; Lee and Lee, 2007; Aujirapongpan et al, 2010; Smith and Mils, 2010; Smith et al, 2010). This paper applies Gold and et al. (2001) model for these two capabilities.

\subsubsection{Knowledge infrastructure capabilities}

Knowledge infrastructure capabilities point to those factors supporting knowledge management activities in the 
organizations and contribute to creation of competitive advantage in organizations.

\subsubsection{Technology}

The element of technology in knowledge infrastructure involves information technology systems allowing the integration of information and knowledge in the organization and providing the creation, transfer, storage and protection of knowledge resources in the organization. Although, the existence of a proper technology infrastructure is a necessity for knowledge management but the researches which studied the link between the information technologies and organizational performance indicators have remained inconclusive and have failed to explain a direct relationship between the information technology and performance (Emadzadeh et al, 2012). For example, Powell and Danet (1997) found that information technology does not increase the organizational performance solely, but it is required to combine with other human and labor capitals. Additionally, Teece et al (1997) stated that lack of a relationship between technology and performance can be due to this reason that technology, information systems resources, can be easily copied and transformed to a weak competitive advantage.

\subsubsection{Organizational culture}

Organizational culture is considered as a complicated set of values, beliefs, behaviors, and symbols affecting the knowledge management in organizations $(\mathrm{Ho}, 2009)$. Thus, a friendly knowledge culture is regarded as that the main factors influencing the knowledge management and application of its outcomes (Miils and Smith, 2010). Sin and Tse (2000) concluded that organizational culture values such as consumer orientation, service quality, informality, innovation are significantly related to organizational performance.

Change in organizational culture is considered also as a necessary factor implementation of knowledge management. So, the ability of an organization to learn, develop and share knowledge depends on the culture. Therefore, it is expected that the positive changes in culture affect the organizational performance and accelerate the other improvements in different parts of the organization.

\subsubsection{Organizational structure}

Organizational structure consists of organizational hierarchy, rules and regulations and reporting relationships and is regarded as a tool for coordination and control (Herath, 2007) by which organizational players can be directed toward the organizational effectiveness. Most of the knowledge management theorists believe that change in the structure of an organization, such as movement from hierarchical forms to flatter network forms, is effective for knowledge creation and transfer. Such wide changes are related positively to improved performance of the organization in both financial and service terms (Miils and Smith, 2010). Thus, it is expected that:

$\mathrm{H}_{1}$ : There is a positive relationship between knowledge infrastructure and organizational performance.

$\mathrm{H}_{1-1}$ : There is a positive relationship between organizational culture and organizational performance.

$\mathrm{H}_{1-2}$ : There is a positive relationship between organizational structure and organizational performance.

$\mathrm{H}_{1-3}$ : There is a positive relationship between technology and organizational performance.

\subsubsection{Knowledge process capabilities}

As it was defined in knowledge management, acquisition, creation, transfer, storage and application of knowledge are the main components of knowledge management which are known as the knowledge process capabilities.

The most accepted definition of knowledge management relates to organizational process capabilities which develop and apply knowledge in order to search and promote the organizational objectives such as long term performance, value added or competitive advantage. Knowledge management capabilities are necessary to enable the organization with knowledge acquisition, adaptation and transfer in an efficient way which consequently provides a fruitful theoretical foundation to define the main aspects of organizational capabilities (Nguyen and Neck, 2010).

There is no consensus about the knowledge management processes. Many scholars such as Probst et al (2000); Heisig (2001); Gold et al (2001); Bhatt (2001); Alavi and Leidner (2001); Lee and Choi (2003); Lawson (2003); Nielsen (2006) mention different types of knowledge management processes. Gold et al (2001) introduced four stages for knowledge processes: 


\subsubsection{Knowledge acquisition}

Acquisition refers to the ability of an organization to identify access and collect the internal and external knowledge which is necessary for its activities (Gold et al, 2001; Zahra and George, 2002). Access to knowledge can involve many different aspects such as creation, sharing and distribution. Knowledge acquisition reflects almost a subset of attractive capabilities of a firm and can be considered more specifically as a potential capability reflecting the ability of a firm to use its knowledge in order to create advantage but it does not guarantee its effective application.

\subsubsection{Knowledge transfer}

Effective usage of the knowledge in business requires the conversion of acquired knowledge from internal and external resources to organizational knowledge. These conversion processes which happen along with the supply of data, information and knowledge cycle is transient and have to covert data into information and information into organizational knowledge in order to maximize the benefits of this process (Bhatt, 2001). So, it is expected that knowledge conversion process can influence the performance outcomes.

\subsubsection{Knowledge application}

Knowledge application involves those activities showing that the organization apply its knowledge (Bhatt, 2001). Moreover, knowledge application means activating knowledge to create value in the organization which can be reflected in innovations, creations and new products (Miils and Smith, 2010). Droge et al (2003) believed that companies will be successful in creating competitive advantage in the long run if they produce knowledge with lower cost and higher speed compared to competitors and apply it effectively and efficiently.

\subsubsection{Knowledge protection}

Protection of knowledge is necessary for performance and effective control in the organization which regularly includes the usage of copyright and patents with the information technology systems allowing the knowledge to give users the right of their usage through file name, username, passwords and shared protocols (Lee and Young, 2000). However, protecting knowledge is often somewhat challengeable since the copyright laws which have legislated to protect knowledge are restricted when they face with the knowledge environment. Contrary to these restrictions, the knowledge protection process has not to be disregarded. Protecting the knowledge against its misuse is necessary to maintain the competitive advantage of the company (Emadzade et al, 2012). Therefore, it is expected that:

$\mathrm{H} 2$ : There is a positive relationship between the knowledge process capabilities and organizational performance.

$\mathrm{H} 2-1$ : There is a positive relationship between knowledge acquiring and organizational performance.

$\mathrm{H} 2-2$ : There is a positive relationship between knowledge transfer and organizational performance.

$\mathrm{H} 2-3$ : There is a positive relationship between knowledge application and organizational performance.

$\mathrm{H} 2-4$ : There is a positive relationship between knowledge protection and organizational performance.

\subsection{Organizational performance}

Organizational performance is a broad concept consisting of what the company produces and those areas which interacts with them. In other words, organizational performance refers to the ways by which company achieves its organizational and social goals and the responsibilities that it undertakes ( $\mathrm{H} 2-1$ : There is a positive relationship between knowledge acquiring and organizational performance (Haghighi et al, 2011).

Organizational performance is a multidimensional concept investigating the organization status compared to competitors. One main view states that organizational performance should not be examined just by financial performance but the other organization dimensions which contribute to value creation for the organization and customer should be also considered. Many researches have been conducted to scrutinize the effects of knowledge management on organizational performance (Makeen et al, 2006). But, most of these researches concentrate on financial outputs such as cost and profit and neglect the non-financial outputs such as operation cost, work time reduction, creating new products, and ability to attracts, train, develop and maintaining the talent human resources. Since different dimensions of the performance are affected by knowledge management capabilities, knowledge management systems ought to able to combine the financial and non-financial measures. Lopez and et al (2005)' model applied in the current study to investigate the effect of 
knowledge management on the business performance of the organization. This model uses financial and non-financial dimensions to measure the business performance of the organization as below:

1. Financial/economical outcomes: such as financial profitability, sales growth, profit growth and marginal profit.

2. Innovativeness and competitiveness: such as creating new products, providing high quality products and services, adaptability with environment, generating a positive image for the company in the industry it operates, customers' loyalty and satisfaction and employees' satisfaction.

Due to the importance of the innovation and competitiveness in the success of the organizations at present and the measurement of their effects on financial/economical outcomes of the studied organizations, another hypothesis added to the current study which is as follows:

H3: There is a positive relationship between competitiveness and innovation and financial/economical outcomes.

\section{Literature Review}

There are several researches which have studied the relationship between knowledge management and organizational performance. Most of these researches concluded that there is a positive and significant correlation between these two variables. Gold et al (2001) found that there is a positive relationship between enablers and knowledge management processes and organizational effectiveness. Lee and Choi (2003) concluded that knowledge management enablers have a positive and significant effect on knowledge management processes and knowledge management processes increase organizational creativity and performance. Nguyen and Neck (2010) figured out that knowledge management processes have significant effect on each other and knowledge protection and application have the highest effect on competitiveness. Miils and Smith (2010) showed that knowledge infrastructure capabilities and knowledge process capabilities affect organizational performance positively. Chung (2004) found that knowledge management capabilities have a direct effect on competitive advantage. Lee and Lee (2007) found that knowledge management capabilities including culture, structure, people and technology influence the knowledge management processes directly and these processes affects organizational performance, customer and financial performance, directly too. Miqdadi (2005) showed in his research that there is a significant and positive relationship between the knowledge management capabilities, knowledge management processes and organizational performance. Waluyo and Wibowo (2011) argued that there is no relationship between organizational culture and performance. Seleim and Khalil (2007) concluded that the knowledge application is the sole factor among knowledge management processes which affects the organizational performance.

Table 1. Past researches about knowledge management and organizational performance

\begin{tabular}{|c|c|c|c|}
\hline Author & $\begin{array}{l}\text { Knowledge } \\
\text { Fundamental } \\
\text { Capabilities }\end{array}$ & Knowledge Process Capabilities & Purpose \\
\hline $\begin{array}{c}\text { Gold et al } \\
(2001)\end{array}$ & $\begin{array}{l}\text { Technology, culture, } \\
\text { structure }\end{array}$ & $\begin{array}{l}\text { Knowledge acquisition, transfer, } \\
\text { application and protection }\end{array}$ & $\begin{array}{l}\text { Effects of knowledge management processes and enablers on } \\
\text { American organizational effectiveness }\end{array}$ \\
\hline $\begin{array}{l}\text { Lee and Choi } \\
\quad(2003)\end{array}$ & $\begin{array}{c}\text { Culture, structure, } \\
\text { people and technology }\end{array}$ & $\begin{array}{l}\text { Knowledge creation, socialization, } \\
\text { externalization and combination }\end{array}$ & $\begin{array}{l}\text { Relationship among the components of knowledge management, } \\
\text { enablers, knowledge creation process, organizational creativity and } \\
\text { organizational performance, in Korean organizations }\end{array}$ \\
\hline $\begin{array}{l}\text { Miqdadi } \\
(2005)\end{array}$ & \multicolumn{2}{|c|}{$\begin{array}{l}\text { According to Lee and Choi (2003) plus leadership variable in } \\
\text { knowledge management enablers }\end{array}$} & $\begin{array}{l}\text { Relationship among the components of knowledge management, } \\
\text { enablers, knowledge creation process, organizational creativity and } \\
\text { organizational performance, in Australian organizations }\end{array}$ \\
\hline $\begin{array}{l}\text { Lee and Lee } \\
\text { (2007) }\end{array}$ & $\begin{array}{l}\text { Technology, culture } \\
\text { and structure }\end{array}$ & $\begin{array}{l}\text { Knowledge production, acquisition, } \\
\text { facilitation, presentation, storage, } \\
\text { application, transfer, measurement }\end{array}$ & $\begin{array}{l}\text { Relationship between enablers, processes and organizational } \\
\text { performance in Korean organizations }\end{array}$ \\
\hline $\begin{array}{c}\text { Mils and } \\
\text { Smith (2010) }\end{array}$ & \multicolumn{2}{|c|}{ According to Gold et al (2001) } & $\begin{array}{l}\text { Effect of knowledge management enablers and processes on } \\
\text { organizational performance in Jamaican organizations }\end{array}$ \\
\hline $\begin{array}{l}\text { Nguyen and } \\
\text { Neck (2010) }\end{array}$ & \multicolumn{2}{|c|}{ According to Gold et al (2001) } & Effect of knowledge management processes \\
\hline Chang (2004) & \multicolumn{2}{|c|}{ According to Gold et al (2001) and Lee and Choi (2003) } & $\begin{array}{l}\text { Effect of knowledge management enablers on competitive } \\
\text { advantage in Korean organizations }\end{array}$ \\
\hline $\begin{array}{l}\text { Waluyo and } \\
\text { Wibowo } \\
\text { (2011) }\end{array}$ & Organizational culture & $\begin{array}{l}\text { Knowledge creation, sharing, acquisition, } \\
\text { documentation, application, transfer }\end{array}$ & $\begin{array}{l}\text { Analysis of relationship between knowledge management, } \\
\text { organizational culture and performance in Indonesian organizations }\end{array}$ \\
\hline $\begin{array}{l}\text { Seleim and } \\
\text { Khalil (2007) }\end{array}$ & & $\begin{array}{c}\text { Knowledge acquisitions, documentation, } \\
\text { transfer, creation, application }\end{array}$ & $\begin{array}{l}\text { Relationship between knowledge management processes and their } \\
\text { effects on organizational performance in Egyptian companies }\end{array}$ \\
\hline
\end{tabular}




\section{Conceptual Framework}

The conceptual framework of this research is based on knowledge management dimensions including knowledge process capabilities (knowledge acquisition, transfer, application and protection) and knowledge infrastructure capabilities (organizational culture, organizational structure and technology) derived from Gold et al (2001) and organizational performance involving financial / economical outcomes, competitiveness and innovation derived from Lopez et al (2005). The research conceptual framework has shown in the figure 1.

Figure 1. Research Conceptual Framework

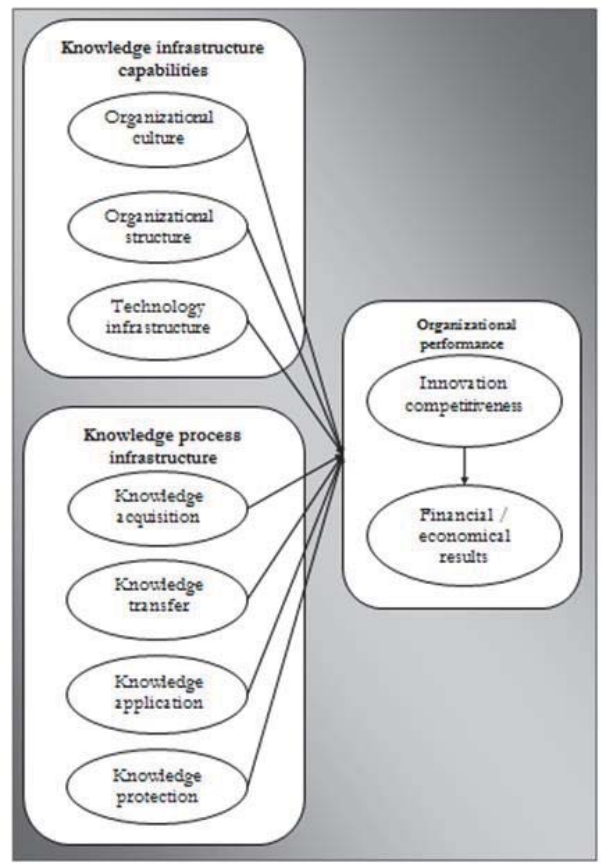

\section{Research Methodology}

The current research is an applied and descriptive survey based on correlation analysis. A correlation research aims to perceive complicated behavioral models through studying the correlation between the variables. The statistical population of the research consists of 252 senior managers of those companies which are the member of Khorasan Razavi Exporters Union since they have more information about the organization in comparison with the others. The sample size is 148 based on Morgan table.

The research tool consists of two 5-point Likert questionnaires. The first one measured the knowledge management including 26 indicators based on Gold et al (2001) and the second was for measuring organizational performance including 16 indicators based on Lopez et al (2005). 200 questionnaires sent by email to the respondents. The response rate was 0.66 and 128 questionnaires used for statistical analysis.

Crobach alph was used to test the reliability of the research tool. This method calculates the internal consistency of those research tools measuring several criteria. To test the construct validity of research variables, we used exploratory factor analysis by principal factors with warimax rotation. Factor loadings more than 0.5 are considered as high and acceptable factor laodings. Table 2 shows the reliability and validity analysis of the research tool.

According to the table 2, crobach alpha value for all the coefficients are higher than the threshold 0.70 , i.e. we can confirm the reliability of the research tool.

The analysis of the knowledge management questionnaire shows the independence of four factors for knowledge process capabilities and independence of three factors for knowledge infrastructure capabilities. Also, the analysis of the organizational performance questionnaire indicates the independence of two factors for this variable. 
Table 2. Summary of reliability test and exploratory factor ananlysis

\begin{tabular}{|c|c|c|c|c|c|c|}
\hline & $\begin{array}{c}\text { Cronbach } \\
\text { alpha }\end{array}$ & $\mathrm{KMO}^{1}$ & $\begin{array}{l}\text { Extracted } \\
\text { factors }\end{array}$ & $\begin{array}{l}\text { Eigen } \\
\text { value }\end{array}$ & $\begin{array}{l}\text { Variance } \\
\text { extracted }\end{array}$ & $\begin{array}{c}\text { Total variance } \\
\text { extracted }\end{array}$ \\
\hline \multirow{4}{*}{ Knowledge process capabilities } & \multirow{4}{*}{0.79} & \multirow{4}{*}{0.86} & Factor 1 & 4.23 & 26.12 & \multirow{4}{*}{59.94} \\
\hline & & & Factor 2 & 3.78 & 19.27 & \\
\hline & & & Factor 3 & 1.59 & 9.11 & \\
\hline & & & Factor 4 & 1.06 & 5.44 & \\
\hline \multirow{3}{*}{$\begin{array}{c}\text { Knowledge infrastructure } \\
\text { capabilities }\end{array}$} & \multirow{3}{*}{0.87} & \multirow{3}{*}{0.83} & Factor 1 & 3.76 & 34.60 & \multirow{3}{*}{76.17} \\
\hline & & & Factor 2 & 1.18 & 29.39 & \\
\hline & & & Factor 3 & 1.11 & 12.18 & \\
\hline \multirow{2}{*}{ Organizational performance } & \multirow{2}{*}{0.81} & \multirow{2}{*}{0.93} & Factor 1 & 6.8 & 37.13 & \multirow{2}{*}{61.67} \\
\hline & & & Factor 2 & 1.89 & 24.54 & \\
\hline
\end{tabular}

${ }^{1}$ Kayser-Meyer-Olkin index indicates the sample adequacy of the selected variables for factor analysis.

\section{Research Findings}

In this section, we firstly present the descriptive analysis and the correlation matrix of data gained from the sample $(n=128)$ in table 3. and table 4. respectively. Then, the model goodness of fit is examined by confirmatory factor analysis to conclude about the research hypotheses.

Table 3. Descriptive analysis of the demographic factors

\begin{tabular}{|c|c|c|c|c|c|}
\hline Gender & \multicolumn{2}{|c|}{$96 \%$ Male } & \multicolumn{3}{|c|}{ 4\% Female } \\
\hline Age & $20-30(18 \%)$ & $31-40(29 \%$ & & $41-50(39 \%)$ & $51-60(14 \%)$ \\
\hline Academic degree & BSc. $(72 \%)$ & \multicolumn{2}{|r|}{$\frac{\text { MA }(22 \%)}{11-15 \text { vears }(15 \%)}$} & \multicolumn{2}{|r|}{ PhD (6\%) } \\
\hline Work experience & $1-5$ years $(29 \%)$ & $6-10$ years $(34 \%)$ & $11-15$ years $(15 \%)$ & $16-20$ years $(9 \%)$ & More than 20 years $(13 \%)$ \\
\hline
\end{tabular}

Table 4. Correlation matrix of research variables

\begin{tabular}{|c|c|c|c|c|c|c|c|}
\hline Variables & 1 & 2 & 3 & 4 & 5 & 6 & 7 \\
\hline 1.Organizational performance & 1 & & & & & & \\
\hline 2.Organizational culture & $0.53^{\star \star}$ & 1 & & & & & \\
\hline 3.Organizational structure & $0.75^{\star \star}$ & 0.30 ** & 1 & & & & \\
\hline 4.Technology & -0.10 & $0.14^{*}$ & $0.17^{*}$ & 1 & & & \\
\hline 5.Knowledge acquisition & $0.51^{* \star}$ & $0.27^{\star \star}$ & 0.31 ** & 0.05 & 1 & & \\
\hline 6.Knowledge transfer & 0.03 & $0.12^{\star}$ & $0.19 *$ & $0.32^{\star *}$ & $0.24^{*}$ & 1 & \\
\hline 7.Knowledge application & $0.74^{\star *}$ & $0.32^{\star \star}$ & $0.68 * *$ & -0.08 & $0.29 * \star$ & -0.11 & 1 \\
\hline 8.Knowledge protection & $0.71^{* \star}$ & 0.31 ** & 0.50 ** & -0.11 & $0.34^{* *}$ & $0.54^{* *}$ & 1 \\
\hline
\end{tabular}

** Correlation is significant at the 0.01 level (2-tailed)

* Correlation is significant at the 0.05 level (2-tailed).

\section{Measurement of the Research Model}

Firstly, in the current research, the relationship between latent variables is estimated by gamma and beta coefficients based on structural equation modeling. In fact, all multiple regression coefficients are calculated by this method and then beta coefficients is measured by $T$ test.

The model goodness of fit is measured by comparison of the estimated covariance matrix for both of the research population and the sample. The most important indices for goodness of the structural linear relationships which explain the variance are $\mathrm{GFI}, \mathrm{AGFI}$ and RMSEA. The variation range of the GFI and AGFI is between 0 and 1 . The higher value of these indices represents the better estimation of model goodness of fit. RMSEA should also be less than 0.05 to represent a well-fitted model. Table 5 shows the results of the research model estimation. 
Table 5. Model Estimation Results

\begin{tabular}{|l|c|c|c|c|c|c|}
\hline Variable & $\mathrm{X}^{2}$ & $\mathrm{df}$ & $\mathrm{X}^{2} / \mathrm{df}$ & $\mathrm{RMSEA}$ & $\mathrm{GFI}$ & $\mathrm{AGFI}$ \\
\hline Knowledge management & 0 & 1 & 0 & 0.000 & - & - \\
\hline
\end{tabular}

According to table 5, since RMSEA is less than 0.1 and $X^{2} / \mathrm{df}$ is less than 3 , it can be concluded that the predicted model is confirmed.

The results of model measurement can be found in table 6 . In which all coefficients are significant except for paths of technology and knowledge transfer to performance.

\begin{tabular}{|c|c|c|c|}
\hline Paths & $\beta$ & $\mathrm{T}$ & Result \\
\hline Org. culture performance _- & 0.22 & 7.17 & Accept \\
\hline Org. structure performance & 0.32 & 8.06 & Accept \\
\hline Technology performance & -0.02 & -0.75 & Reject \\
\hline Knowledge acquisition performance & 0.18 & 5.95 & Accept \\
\hline Knowledge transfer performance & 0.02 & 0.51 & Reject \\
\hline Knowledge application performance & 0.25 & 6.10 & Accept \\
\hline Knowledge protection performance & 0.28 & 7.93 & Accept \\
\hline Knowledge infrastructure capabilities performance $\longrightarrow$ & 0.69 & 14.66 & Accept \\
\hline Knowledge process capabilities performance & 0.13 & 2.78 & Accept \\
\hline Innovation and competitiveness financial results & 0.27 & 4.09 & Accept \\
\hline
\end{tabular}

\section{Conclusion and Discussion}

Today, knowledge and its proper management are considered as one of the basic concepts for organizational success. By applying knowledge management, companies can select relevant information to produce high level of quality in management, compare them with other methods and choose more useful strategies to gain the highest profit (Emadzadeh et al, 2012). There are several researches investigating the relationship between knowledge management and organizational performance. The past researches have confirmed the positive and significant correlation of knowledge management and organizational performance. The current research explained some aspects of knowledge management and the relationship between knowledge management capabilities and organizational performance.

The first principal research hypothesis stated that there is a significant relationship between knowledge infrastructure capabilities and organizational performance which is consistent with the some other research findings such as Gold et al (2001) in U.S.A, Miils and Smith (2010) in Jamaica, Lee and Choi (2003) and Chang (2004) in Korea and Miqdadi (2005) in Australia. Testing the first three secondary hypotheses showed that the organizational culture and structure influence the organizational performance. However, technology has no effect on it. We can conclude that although technology does not influence the performance directly, but it is influential in form of knowledge infrastructure capabilities indirectly along with organizational culture and structure (Mils and Smith, 2010).

The second principal hypothesis illustrating that there is a significant relationship between knowledge process capabilities and organizational performance confirmed since (ddd). Scholars' research findings including Gold et al (2001) in USA, Naguwin and Neck (2010) in Vietnam, Mils and Smith (2010) in Jamaica, Lee and Choi (2003) in Korea, Valio and Vibow (2001) in Indonesia found that knowledge acquisition, knowledge application and knowledge protection are related with organizational performance. But there is no relationship between knowledge transfer and organizational performance. Nagwuin and Neck (2010) showed that there is a significant and positive relationship between each factors of knowledge process capabilities. Mils and Smith (2010) found that there is a significant relationship between knowledge acquisitions, application and protection. They, also, concluded that there is no significant relationship between knowledge transfer and performance. Salim and Khalil (2007) showed that knowledge application is the only factor which influences the organizational performance among the knowledge management processes.

The third principal hypothesis tested the relationship between innovation and competitiveness and financial I economical outcomes. The findings not only supports this assumption but also shows that knowledge management influences the financial / economical outcomes indirectly through innovation and competitiveness. Lopez and et al (2005)' findings in Spain organizations revealed that there is a significant relationship between financial / economical outcomes and innovation and competitiveness. 


\section{Recommendations}

Research recommendations are presented specially for each functional areas of the organizations regarding the model estimation in different parts of them. These recommendations are based on practical solutions for implementation of knowledge management practices in different parts of the companies. We have categorized these recommendations according to the functional parts and units, such as sales and marketing, information technology, and customer relations management in the organization in a way that these are presented especially for each knowledge management capabilities (infrastructure and process) to excel the organizational performance.

Recommendations for knowledge process capabilities

- Designing an information system to identify competitors' products and services and transferring it to the knowledge by internal mechanisms of the organization helps managers to make their decisions by considering several dimensions of competition and gain competitive advantage.

- Making relationship with research and counseling centers to outsource the research services enables managers to gain knowledge and information in the industry they operate and excel their organizational performance.

- Designing customers' database facilitates the possibility of maintaining customers' information in order to customize the services and achieve their knowledge and ideas by which it is possible to create competitive advantage.

- Setting up feedback system, documentation of people knowledge and experience and comprehensive support of creative and innovative people enables the organization to differentiate themselves from the competitors by applying knowledge.

- Setting proper security systems and defining file name, username and password for each organizational user to share information plays an important to prevent the steal of organizational vital information and protect the organization knowledge.

Recommendations for knowledge infrastructure capabilities

- Organizational culture is considered as one the most important factors for implementation of knowledge management in many managerial texts. An appropriate organizational culture can lead to favorable individual and organizational outcomes. Managers are required to level the ground for implementation of knowledge management by creating a participative culture to share knowledge and group work.

- Facilitating the share of knowledge, organizations have to flatten the organizational structure and ease the interpersonal communications in a way that people communicate with each other rapidly and timely. For this purpose, reviewing and amendment of troublesome and problematic rules and regulations for the interpersonal communication process, knowledge sharing and detection of knowledge workers can be very influential.

- Information technology is considered as the fundamental factors for knowledge management success. Particularly, these factors contribute to facilitation of knowledge management processes in organizations. Thus, managers have to plan to develop the required trainings for use of information technology and reinforce the propensity to apply it especially in knowledge sharing practices.

\section{Research Limitations}

- This research is a case study of Khorasan Razavi Exporters Union. Although case studies increase the researchers' insight about the studied population and provide a practical guide, but limit the generalization of the findings to similar populations which is the inner limitation of these types of research.

- The current research used self-express to measure financial / economical outcomes. The main limitation for this method is that managers may overstate or hide their information.

\section{Recommendations for Future Researches}

Obtaining a comprehensive knowledge management model, it is suggested to conduct such researches in other different organizations and companies. It is recommended to combine data mining with knowledge management models in future researches to use explicit and implicit organizational information more efficiently and gain competitive advantages. Since customers are important in organizational success, future studies can measure the effect of knowledge management 
customers (CKM) on organizational performance directly or as a mediating variable.

\section{References}

Alavi, M; Leidner, D. E. (2001), "Review: Knowledge Management and Knowledge Management Systems: Conceptual Foundations and Research Issues", MIS Quarterly, Vol. 25, No. 1, pp. 107-136.

Aujirapongpan, S.; Vadhanasindhu, P., Chandrachai, A. and Cooparat, P. (2010), "Indicators of knowledge management capability for KM effectiveness", Journal of Information and Knowledge Management Systems, Vol. 40, №. 2, pp. 183-203.

Aydin, B. and Ceylan, A. (2009), "The role of organizational culture on effectiveness", Ekonomie a Management $(E+M)$, Vol. 3, pp. 3349.

Bhatt, G. D. (2002), "Management strategies for individual knowledge and organizational knowledge", Journal of Knowledge Management, Vol. 6, No. 1, pp. 31-39.

Chuang, S. H. (2004), "A resource-based perspective on knowledge management capability and competitive advantage: an empirical investigation", Expert Systems with Applications, Vol. 27, No. 3. pp. 459-465.

Dro"ge, C., Claycomb, C. and Germain, R. (2003), "Does knowledge mediate the effect of context on performance? Some initial evidence", Decision Sciences, Vol. 34, No. 3, pp. 541-68.

Emadzade, M; Mashayekhi, B. and Abdar, E. (2012), "Knowledge management capabilities and organizational performance", interdisciplinary journal of contemporary research in business, Vol. 3, No 11, pp. 781-790.

Gold, A. H.; Malhotra, A. and Segars, A.H. (2001), "Knowledge management: an organizational capabilities perspective", Journal of Management Information Systems, Vol. 18, No. 1, pp. 185-214.

Heisig, P. (2001), Business process-oriented knowledge management, in Mertins, K., Heisig, P. and Vorbeck, J. (Eds), Knowledge Management: Best Practices in Europe, Springer, Berlin, 13-36.

Herath, S. K. (2007), "A framework for management control research", Journal of Management Development, Vol. 26, No. 9, pp. 895915.

Ho, C. (2009), "The relationship between knowledge management enablers and performance", Industrial Management \& Data Systems, Vol. 109, No. 1, pp. 98-117.

Matin, K. E. and Kashani, H. B. (2012), "Comparing Degree of Readiness for Implementation of Knowledge Management in Public and Private Universities in Iran", Interdisciplinary journal of contemporary research in business, Vol. 4, No. 4, pp. 623-634.

Kostas Metaxiotis, Kostas Ergazakis, (2008) "Exploring stakeholder knowledge partnerships in a knowledge city: a conceptual model", Journal of Knowledge Management, Vol. 12 №.: 5, pp.137 - 150

Lawson, S. (2003), Examining the relationship between organizational culture and knowledge management, Doctoral dissertation, Nova Southeastern University.

Lee, C. C. and Yang, J. (2000), "Knowledge value chain", Journal of Management Development, Vol. 19, No. 9, pp. 783-93.

Lee, H., Choi, B. (2003), "Knowledge management enablers, processes, and organizational performance: an integrative view and empirical examination", Journal of Management Information Systems, Vol. 20, No. 1, pp. 179-228.

Lee, L. T. and Sukoco, B. M. (2007), "The effects of entrepreneurial orientation and knowledge management capability on organizational effectiveness in Taiwan: the moderating role of social capital", International Journal of Management, Vol. 24, No. 3, pp. 549-73.

Lindner, L.; Wald, A. (2010), "Success factors of knowledge management in temporary organizations", International Journal of Project Management, Vol. 29, No. 7, pp. 877-888.

Lo'pez, S. P, Montes, J. M. and Orda's, C.J. (2005). Organizational learning as a determining factor in business performance, The Learning Organization, Vol. 12 No. 3. pp. 227-245.

McKeen, J. D. Zack, M. H. \& Singh, S. (2006), "Knowledge management and organizational performance An exploratory survey". In Proceedings of the 39th annual Hawaii international conference on systems sciences: pp. 1-9.

Metaxiotis, K., Ergazakis, K. and Psarras, J. (2005), "Exploring the world of knowledge management: agreements and disagreements in the academic/practitioner community", Journal of Knowledge Management, Vol. 9, No. 2, pp. 6-18.

Migdadi, M. M. (2005), "An integrative view and empirical examination of the relationships among knowledge management enablers, processes, and organizational performance in Australian enterprises", PhD thesis, School of Economics and Information Systems, University of Wollongong,

Mills, A. M., Smith, T. A. (2011), "Knowledge management and organizational performance: A decomposed view", Journal of Knowledge Management", Vol. 15, No. 1, pp. 156-171.

Nguyen, Q. and Neck, P. (2009), "Knowledge Management as Dynamic Capabilities: Does It Work in Emerging Less Developed Countries?", Journal of Knowledge Management, Vol. 3, No. 3, pp. 505-520.

Nielsen, A. P. (2006), "Understanding dynamic capabilities through knowledge management", Journal of Knowledge Management, Vol. 10, №. 4, pp. 59-71.

Nonaka, I. and Konno, N. (1998), "The concept of "Ba": building a foundation for knowledge creation", California management review, Vol. 40, No. 3, pp. 40- 54 .

Probst, G., Raub, S. and Romhardt, K. (2000), Managing Knowledge: Building Blocks for Success, New York: John Wiley \& Sons. Chichester.

Powell, T. C. and Dent-Micallef, A. (1997), "Information technology as competitive advantage: the role of human, business, and technology resources", Strategic Management Journal, Vol. 18, No. 5, pp. 853-77. 
Rivera-Vazquez, J. C., Ortiz-Fournier, L. V. and Rogelio Flores, F. (2009), "Overcoming cultural barriers for innovation and knowledge sharing", Journal of Knowledge Management, Vol. 13, No. 5, pp. 257 - 270.

Seleim, A. and Khalil, O. (2007), "Knowledge management and organizational performance in the Egyptian software firms", International Journal of Knowledge Management, Vol. 3, No. 4, pp. 37-66.

Sin, L. Y. M. and Tse, A. C. B. (2000), "How does marketing effectiveness mediate the effect of organizational culture on business performance? The case of service firms", Journal of Services Marketing, Vol. 14, No. 4, pp. 295-309.

Sun, P. (2010), "Five critical knowledge management organizational themes", Journal of Knowledge Management, Vol. 14, No. 4, pp. 507-523.

Teece, D.J., Pisano, G. and Shuen, A. (1997), "Dynamic capabilities and strategic management", Strategic Management Journal, Vol. 18, No. 7, pp. 509-33.

Theriou, G.N., Chatzoglou, P.D. (2008), "Enhancing performance through best HRM practices, organizational learning and knowledge management: A conceptual framework", European Business Review, Vol. 20, No. 3, pp. 185-207.

Tian, J., Nakamori, Y. and Wierzbicki, A. P. (2009), "Knowledge management and knowledge creation in academia: A study based on surveys in a Japanese research university", Journal of Knowledge Management, Vol. 13 No. 2, pp. 76-92.

Waluyo, R. and Wibowo, M. A. (2011), "Modelling of Knowledge Management, Corporate Culture and Performance in Construction Firms", Journal of Basic and Applied Scientific Research, Vol., 1 No. 11., pp. 2286- 2292.

Wen, Y. (2009), "An effectiveness measurement model for knowledge management", Knowledge-Based Systems, Vol. 22, No. 5, pp. 363-367.

Lee, Y.-C. and Lee, S.-K. (2007), "Capabilities, processes, and performance of knowledge management: A structural approach". Hum. Factors Man., 17: 21-41.

Zahra, S. A. and George, G. (2002), "Absorptive capacity: a review, reconceptualization, and extension", Academy of Management Review, Vol. 27, No. 2, pp. 185-203.

Zins, C. (2007), "Conceptual Approaches for Defining Data, Information, and Knowledge", Journal of the American Society for Information Science and Technology, Vol. 58, No. 4, pp. 479- 493. 